https://doi.org/10.3126/pragya.42027

\title{
Mistica: A Marxist Praxis
}

\section{Dr. Gokarna Prasad Gyanwali*}

\begin{abstract}
The Mística is the symbolic or dramatic social movement of Marxism initiated by Brazilian Landless Rural Workers. It is the popular movement practiced by the Communist parties and socialist organizations of the world. It was developed from Latin American liberation doctrine and interpreted as love for a cause, solidarity experienced in collectivity, symbolic presentation of the socialist movement, and belief in radical change. It is one type of philosophical movement which has a demonstrative attachment, praxis of pedagogy, behavioral collectivity, and cultural movement to change the social world guided by the theory of Karl Marx. It has political roots against the homogenization of culture, imperialism, and capitalist domination of the world. It uses art, music, drama, activity, symbol, media, and other modern tools which help the people for emancipation. This article will demonstrate some of the major aspects of mistica based upon the field observation of Brazil and Nepal.
\end{abstract}

Keywords: Mistica, emancipation, landlessness, praxis, Pedagogy

\section{Introduction/ Background}

Etymologically, the term mística can be translated as the 'mystic' or maybe more faithfully the 'mystery'. The word mistica not only refers to specific performances but also to the spirit with which they are undertaken and their central purposes to encourage commitment to the movement, identification with the movement as a central element of one's identity, the aspiration to the ideal future (utopia), and the belief that by their efforts they will secure that future (Hammond, 2014). This is the major activity of workers' organizations, peasants' organizations, and the members of the communist parties of Latin America especially by Landless Workers’ Movement. Movimento dos Trabalhadores Rurais Sem Terra (MST) has been involved in daily, often early in the morning, and at specific events. Though the MST is deeply influenced by Liberation Theology, the popular movement that swept Latin America's large Catholic community from the 1960s and interpreted Jesus' message through the lens of social justice and Marxism, but mística is not a Christian ceremony. Instead, the ceremony is a celebration and evocation of a living thread of those who have struggled for freedom and justice across history (Udi, 2013). Now it is practiced by other member organizations of MST and its affiliated Marxist schools of Africa, America, and Asia. Mística is not only an emotional attachment to the Marxist ideology, but

*Dr. Gyanwali is an Assistant Professor of Anthropology, Patan Multiple Campus, TU, Nepal 
it is the praxis of pedagogy, behavioral performances, and cultural practices developed through the social movement. It is a symbolic presentation based on the socialist philosophy and dialectical materialism to educate and empower the people. The movement incorporates these practices into its struggles, keeping the inspiration alive without institutionalizing the mística (Issa, 2007). It is the emotional attachment of Marxist ideology, the behavior of the Marxist cadre, an imagination of the results of the socio-political movements, and the strength of the organizational power (Albritton \& Mohseni, 2019).

\section{The objective of the paper}

The overall objective of this article is to thrash out the theory and practices of mistica in Marxist organizations of Nepal and Brazil. The specific objective is to introduce the concept of mistica, the theory behind it, and practices in the socialist and Marxist parties of the world.

\section{Methodology and Study Area}

This paper draws on two months of fieldwork in several land reform communities and the school of MST in Gurerama near Sao Paulo Brazil and a one-month field study of the Madan Bhandari School of Asia. The research is grounded in extensive participantobservation in school and community life that draws information from oral histories, local historical documents from the school library, and conversations from school administration, teachers, and students. Initially, I built relationships with the staff of the school than the people living in neighboring settlements of the school. These relationships were initially mediated by ties of friendship and kinship that crossed settlements, and subsequently as a researcher working independently from local institutions. I built harmonious relationships of MST's different levels of leadership, and some self-identify as activists or militant, none belong to the MST's extra-local leadership. With some exceptions noted above, a good deal of research on the MST focuses on the most visible movement leaders and official narratives. (De-Vore, 2015).

To better understand the different aspects of mistica, I studied the educational motives of MST and its associated organizations. Ideologically, the MST is influenced by Latin American socialist movements and Liberation mysticism and thus emphasizes equality, the transformation of the society, sustainable agriculture, co-operativism, and protection of the environment (Perruaelt, 2008). The MST was officially founded in 1984 at Cascavel in the southern Brazilian state of Parana, although its roots go back to the peasant uprisings and the organizational activities of progressive wings of the Roman Catholic Church before and during the military dictatorship of the 1960s. As of 2014, the movement has led more 
than 2,500 land occupations with about 370,000 families and has won nearly 18.75 million acres (7.5 million hectares) of land as a result of their direct action (MST, 2015).

The MST believes that the education of rural communities must ensure that rural workers, men, and women alike, take ownership of their history. They thus become agents of radical change, with consciousness needed to transform reality and the conditions surrounding them. One of the most important mottos of MST is: "All Landless, Men, and Women, Must Study." Education and training play a fundamental role in allowing the settlers and encamped families living in the Agrarian Reform areas to join forces and organize to transform their conditions of life and make it possible for many others to have access to land and more dignified life. This can only be achieved through dedication and concrete means and educational institutes like Florestan Fernandes National School (ENFF) ensure their motto and objectives. The ENFF is for people's militants, identified with the cause of the working class and the ideals of a socialist society. Under the coordination of the MST, the ENFF holds courses for the militancy of Brazilian social movements, for all of Latin America and some countries in America, Africa, and Asia. The name, Florestan Fernandes, is a tribute to one of the greatest Brazilian thinkers, who put the principle of scientific knowledge at the service of the liberation of the Brazilian working class. Its maintenance and operation are provided for by national and international support and solidarity. The School keeps a policy decision to not receive government funding, to maintain political and ideological autonomy, and build its financial support through the solidarity and contributions of the working class. Out of this ENFF, there are several permanent and mobile schools and colleges of Brazil as well as out of Brazil also practicing the mistica on their daily routine. So, my research field was concentrated on the school established by MST, the members of MST, the communities settled by MST, and its allied organizations like Madan Bhandari School of Asia (MBSA), Nepal.

\section{Theoretical Framework of Mistica}

Mistica practice is based on the theory of socialism propounded by Marx-Lenin and Pedagogy of oppressed propounded by P. Freire, a Brazilian educationist. But mistica directly does not support any theory, it is just the cultural and educational practice applied in their daily activities as well as the educational system. It is one type of public sphere practiced by the Marxist organization to empower the people. It is a political performance applied by MST to aware the mass of people for their public transformation. German sociologist J. Habermas explained this type of activity as a public and private sphere. According to Habermas (1989), individuals and groups could shape public opinion, giving direct expression to their needs and interests while influencing political practice. Flynn (2015), has discussed how the mística of the Landless Workers' Movement of Brazil can be 
understood as a performance through which change is imagined through the collective elaboration of meaning. He highlights how the MST's stylized form of performance is latent with the pedagogy of Paulo Freire, intending to enable movement members to envisage change within themselves and also collective change in the conception of political subjectivity. Associated with Freire's (1967) work and general Marxist theory, praxis is the application of theory to practice. Learned concepts acquire meaning as theory is applied to one's experience. The purpose of mística as praxis is communicating concepts and messages through symbolism that serve to educate largely unlettered people on a variety of subjects political, cultural, and historical while asserting their identity in the process. The pedagogical outcome of mística is therefore not only knowledge but the creation and reassertion of norms - values and the construction of a class and culture-based identity that leads to empowerment (Issa, 2007). MST practices mistica in their educational institution as well as their sister organization as a resistance movement against the anti-people government and domination of capitalism. But it is mostly applied in an educational institution as a pedagogy based on the theory of P. Freire.

Over a lifetime of work with revolutionary organizers and educators, radical educator Freire (1968) created an approach to emancipatory education and a lens through which to understand systems of oppression to transform them. He flipped mainstream pedagogy on its head by insisting that true knowledge and expertise already exist within people (tifidancer blog, 2020). They need no "deposits" of information, nor do they need leftist propaganda to convince them of their problems. What is required to transform the world is dialogue, critical questioning, love for humanity, and praxis, the synthesis of critical reflection and action. In sociology and anthropology, this type of perspective was introduced by E. Goffman in 1959 in the book "The Presentation of Self in Everyday Life". In the name of dramaturgical perspective, Goffman uses the metaphor of theatrical production to offer a way of understanding human interaction and behavior. Within this perspective, social life is a "performance" carried out by "teams" of participants in three places: "front stage," "backstage," and "off-stage" (Cole, 2019). It also emphasizes the importance of the "setting," or context, in shaping the performance, the role a person's "appearance" plays in social interaction, and how the "manner" of a person's behavior shapes interaction and fits into and influences the overall performance. Mistica is also concerned with the preparation, performance, and its impact on the audience of people and based on the Marxist ideology of educational performances.

\section{Mistica Practice}

The MST including its international school (ENFF) and their sister organizations has been practicing mistica as their daily work. Mistica is the initial and inaugural session of their 
political and educational activities. Similar activities are also found in Nepal including South Asia and Western countries. In Nepal and South Asia, inauguration means "Udghatan" (a Sanskrit word) where 'Ud' means to activate or manifest. Commencing a function or program by invoking different activities is called udghatan. It is performed by symposiums, music recitals, literary meets, lighting of a ceremonious lamp, etc. Before instituting a stage of the program, coconut should be broken and the actual inauguration should be done by lighting a formal lamp. The objective of these activities in South Asia, mainly in India and Nepal is to purify the premises. Since the stage is associated with the mission of spreading knowledge, the ritual of lighting a ceremonious lamp gains importance. Similarly, in the western tradition of inaugurating a program is done by cutting a ribbon (https:/www.hindujagruti.org/hinduism/hinduism-practices/inaugurationceremony) or by clapping the hand. It is one of the ceremonial activities of sacred initiation that is mostly traditional and ritualistic but it has not been proved by scientific communities.

In Latin America, especially MST has been practicing mistica as an inaugural program but it has a vast and hidden meaning. I have discussed here the practice of mistica in the context of ENFF (MST). Like other ceremonies, we (me along with my group) have taken part along this journey of mistica and found them shy, awkward, self-conscious of the theatricality of the performance, yet keen to participate with an open heart and mind. We try to calm the over-analytical and distancing mind and feeling academic training and ironyloving post-modern culture has cultivated (Udi, 2013). Instead, we try to join in song, dance, and the essence of the event, opening ourselves to the new experience. Soon a warm feeling of solidarity emerges amongst us in the group and a sense of historical continuity with others also striving for a better world. This thread in the mística is probably not far from the nationalistic movement of Nelson Mandela, South Africa, and M. K. Gandhi, India. It carries the integration of the truth or soul-force, a spiritual strength that overcomes injustice in the world seeking to show the true nature of things. My experiences here, where I have spoken of the strong affectivity, emotional attachment, warmth, and solidarity at the ENFF are not necessarily reflective of the Movement as a whole, a very broad and diverse collection that includes hundreds of thousands of families spanning the continental scale of Brazil and its many local cultures. But at least here in this place of learning these qualities of friendship and solidarity, so often absent or repressed in more traditional academic spaces, were very much present.

We also moved to the rural areas educational institutions constructed with the help of MST, which has the same types of affinity and attachment. I think it is the ideological and classbased attachment towards the working class unity around the world. They developed a common culture and qualities, in the learning places and taught us a great deal about a 
whole sphere of being in the world and being together emotionally, socially, spiritually, and academically. Experiencing how learning spaces can accommodate and nurture these dimensions of our being, as we have tasted along this journey, has been inspirational for us showing that there are some powerful ways of re-imagining higher education (Udi, 2013). These collective consciences and solidarity through the mistica are an inspiration for the future of the socialist movement in the world.

\section{Experiencing Mistica from the field}

In one of the mística we attended and observed at a school of the village, were the images of Zumbi, the 17th-century African prince and runaway slave who led a colony of former slaves in their battle against the Portuguese crown in Brazil. This scene is surrounded by flowers and candles, sat along that of Steve Biko, the South African activist, founder of the black color movement, and intellectual who fought against apartheid and who was murdered by the South African police in the 1980s. It was the historical movement shown by local people and students in the name of mistica. The mística also involved singing and poetry and even some dancing.

Most of the Mística performances are embedded into the cultural politics and are used to open meetings at which hundreds of people are in attendance. In these performances, the community or institutions is represented as embedded within wider schemes of the global political economy, the political symbols of the movement, revolutionary flag, the country national flag and anthem, and the props that signify the reach and power of multinational corporations all go to demonstrate how political subjectivities elaborated in relational and reflexive spaces are never disengaged from the spheres in which MST leaders understand their struggle to take place. One of the interesting facts about mística, however, is the extent to which the performance is subject to control (Flynn, 2015).

Mística abounds in symbols, material objects with a deeper meaning, expressing aspects of the struggle for land and the hope for the future. Some symbols relate to the peasants, land of indigenous people, and agriculture, others to social and political struggle. They incorporate farm products seeds, plants, even animals and tools scythes, machetes, hoes, often held raised in a position of defiance. The negative counterparts of these symbols are the symbols of the life of the city, to which the peasant deprived of access to land is forced to migrate. Political struggle is symbolized by the various pictures, videos, and flags, the map of the country, and also by symbolic behavior - singing, assembling in groups, and assuming postures that display defiance. Again, there are also negative symbols, representing the political forces that impede the realization of their goals - the landowner, the banker; more recently, agribusiness, and the International Monetary Fund (Issa, 2007; Lara, 2005 \& Medeiros, 2001). I observed a mistica performed by the students of Madan Bhandari School of Asia, last year. They performed a historical movement of the 1950s and 
the intervention role of Indian leaders towards the freedom and sovereignty of Nepal. They performed the flag of Nepal, the map of both countries, and the revolutionary slogans of that liberation movement. Some of the symbols convey meaning indirectly and appeal to the emotions as much as to the intellect; the purpose is to create a feeling as much as it is to convey a rationally articulated set of beliefs. The nonverbal, nonintellectual aspect of mystical experience is conveyed by physical, kinetic aspects of performance in the mística (Lara, 2007 \& Boff, 2004).

Most of the mística embodies artistic presentation including performance, plastic arts, dance, and music. The artistic elements constitute mobilizing forces of the sense of belonging and the establishment of a distinction between 'us' and 'them'. Songs, dance, and theater contribute to identity formation: they are "the expression of a collective feeling that unites, identifies and strengthens their spirit of resistance and struggle" (Harnecker, 2001). Most importantly, mística contributes to the formation of collective identity. Shared identity makes struggle possible and has to be cultivated. Correlatively, mística identifies an enemy, and other over-against whom the working class defines themselves and their struggle. So the unity is produced within the group and at the same time separates the group from adversaries in conflict. The MST and its allied organizations have devoted significant resources and attention to the cultivation of identity. Identity and consciousness level is essential to any movement because while movements may be rationally organized and instrumentally directed, their success depends on the voluntary adherence of their followers. The distant possibility of material reward cannot by itself win that adherence; the main incentive is the solidarity they feel with their fellow activists (Hammond, 2014). Místicas are performed on a variety of occasions: group meetings, gatherings, assemblies, demonstrations, congresses, and occupations (MST, 1986) which establishes the separate identities, separate feelings, and working-class solidarity around the globe. But there is one debate whether mistica is essential for Nepal including other socialist or socialist-oriented countries? Is it a real movement or a resistance movement? If any political organization has no right to direct protest against the government, it will be suitable, otherwise, it should not be followed as a ritualistic activity.

\section{Conclusion}

Although the mistica literature was written that the liberation theology, the Cuban revolution, and Marxist ideologies had a wide influence among those movements, for the majority of the organizations, this cannot be stated. Especially the Cuban revolution and Marxist ideologies resulted to have more influence on the mistica performances. The liberation theology was also more often mentioned by the member of organizations as an important influence, but considering the research results, it was not the principal, awareness maker of the poor situation of most of the people. Most people became aware of the poor 
situation by looking at what was happening in society, which is symbolized by the Mistica. So it is very popular with the common people of the world, especially the working class. Mistica performances are the lived experiences of the working class who has been suffering from socio-economic inequalities, dominated by the ruling class. So, it is very popular among the people of the world which symbolizes the emotion and feeling of the people who believe in the social revolution and the true emancipation of the people.

\section{References}

Boff, L. (2004). Mística e religião. Retrieved from, https://leonardoboff.org/2014/03/16/o-povobrasileiro-um-povo-mistico-e-religioso/

Cole, N.L. (2019). Goffman's front stage and back stage behavior: Understanding a key sociological concept, retrieved from https://www.thoughtco.com/goffmans-front-stage-andback-stage-behavior-4087971.

DeVore, J. (2015). The Landless invading the landless: participation, coercion, and agrarian social movements in the cacao lands of southern Bahia, Brazil. The Journal of Peasant Studies. Retrieved from, http://dx.doi.org/10.1080/03066150.2014.990447.

Flynn, A. (2015). Re-imagining political subjectivities: Relationality, reflexivity, and performance in rural Brazil. Palgrave Macmillan: UK

Freire, P. (1968). Pedagogy of the oppressed. Retrieved from, https://beautifultrouble.org/theory/pedagogy-of-the-oppressed.

Lara Junior, N. (2005). A mística no cotidiano do MST: a Interface entre Religiosidade Popular e Política. Ph.D. thesis, Pontifícia Universidade Católica de Sao Paulo.

Habermas, J. (1989) Structural transformation of the public sphere. Cambridge, Mass: MIT Press.

Hammond, J. J. (2014). Mistica, meaning, and popular education in the MST. Interface: a journal for and about social movements Article Volume 6 (1): 372 - 391. Retrieved from, http://www.interfacejournal.net/wordpress/wp $\quad$ content/uploads/2014/06/Interface-6-1Hammond.pdf

Issa, D. (2007). Praxis of empowerment: Mística and mobilization in Brazil's Landless Rural Workers’ Movement, Latin American Perspectives, Vol 34, Issue 2, pp. 124 - 138.

Medeiros, L. S. (2001). Sem terra, assentados, agricultores familiares: considerações sobre os conflitos sociais e as formas de organização dos trabalhadores rurais brasileiros. In ¿Una nueva ruralidad en América Latina? Edited by Norma Giarracca, 103-28.

Perruaelt, T. (2008). Latin American social movements: A review and critique of the geographical literature, retrieved from https://doi.org/10.1111/j.1749-8198.2008.00142.x

Tifidancer (2020). Paulo Freire's pedagogy of the oppressed (blog), retrieved from https://teifidancer-teifidancer.blogspot.com/2020/09/paulo-freires-pedagogy-of-oppressed.html

Udi (2013). Visiting a sociable movement, the MST. Retrieved from, http://enlivenedlearning.com/2013/09/02/visiting-a-sociable-movement-the-mst/ Brazil, enff 